\title{
The early genealogy of Edward Jenner and the Jenner family of Kempsford, Marston Meysey and Meysey Hampton
}

Received: 19 October 2017

Accepted: 25 November 2017

Additional information is available at the end of the article.

KEYWORDS: Edward Jenner; Berkeley Standish; Kempsford; Gloucestershire; Wiltshire; wills; vaccination; smallpox
John William Chandler

Abstract: Edward Jenner (1749-1823) was one of the most important British historical medical figures and is considered the pioneer of vaccination and father of immunology. He was born and practised in Berkeley, Gloucestershire and his genealogy back to 1612 in Standish, Gloucestershire, is well documented. Many biographies about his life and work exist. A single document in the Gloucestershire Archives establishes the Standish Jenners as a cadet branch of the Jenner family of Kempsford and its surrounding parishes. This study demonstrates the utility of wills as genealogical resources, especially prior to the start of parish registers, and highlights the importance of sources such as deponents in legal cases in providing key locational genealogical information. The remarkably high frequency of early Jenner wills in Gloucestershire and Wiltshire, coupled with standard genealogical research, has enabled a pedigree to be established extending that of Edward Jenner by three generations, to approximately 1500 and collaterally, to important landowners in seventeenth-century Gloucestershire and Wiltshire. This represents the most complete genealogy to date of the Jenner family, and records confirm the existence of the family in the area in the early fifteenth century. The pedigree also illustrates the potential upward social mobility that existed in seventeenth-century Gloucestershire.

\section{Introduction}

Edward Jenner MD, LLD, FRS (Figure 1) was born on 17 May 1749, ${ }^{1}$ in Berkeley, Gloucestershire, the son of Stephen Jenner, MA, BD, rector of Rockhampton and the vicar of Berkeley. He was a country doctor and is considered one of the most important medical figures of all time and the father of immunology. He died on 26 January 1823 at his home in Berkeley. ${ }^{2}$ In 2002, Jenner was included among the BBC's list of the 100

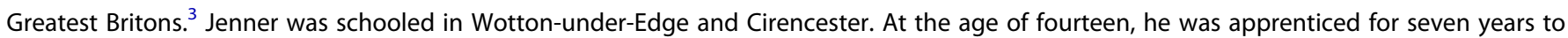
Daniel Ludlow, a surgeon of Chipping Sodbury. ${ }^{4}$ In 1770, he trained in medicine under John Hunter at St. George's Hospital in London and returned to Berkeley in 1772, where he became the local practitioner and surgeon. ${ }^{5}$ Despite establishing medical practices in London and Cheltenham, Jenner remained in Berkeley for the rest of his life. He was elected to the Royal Society in 1788 for his published account of the behaviour of the cuckoo, ${ }^{6}$ and obtained his MD from the University of St. Andrews in 1792. ${ }^{7}$ He was awarded an honorary MD from Oxford University in $1813^{8}$ and was appointed physician extraordinary to King George IV in $1821 .{ }^{9}$ Despite receiving international accolades during his lifetime, and against popular belief, he was never knighted, but did receive the Freedom of the cities of London, Glasgow, Edinburgh and Dublin. ${ }^{10}$

In 1788, during a smallpox outbreak in Gloucestershire, Jenner noted that individuals who worked with cattle and contracted cowpox (a milder form of smallpox) never contracted smallpox. This was common knowledge in the countryside. Exposure to smallpox induced immunity for life, and variolation (deliberately inoculating someone with a milder form of smallpox, to avoid subsequent, more serious, natural infection) was commonly practised in Africa, India, China and the Ottoman Empire ${ }^{11}$ and had been introduced to Britain in 1721 by Lady Mary Wortley Montagu (1698-1762), wife of Edward Wortley Montagu, British Ambassador in Istanbul. ${ }^{12}$ However, variolation still presented a small risk of death (for example, a son of George III died in this way) ${ }^{13}$ and could also lead to smallpox outbreaks. In 1796 , Jenner famously inoculated eight-year-old James Phipps in the arm with fluid from cowpox vesicles from a milkmaid. When Phipps

(C) 2017 The Author(s). This is an open access article distributed under the terms of the Creative Commons Attribution License (http://creativecommons.org/ licenses/by/4.0/) 




Figure 1. Portrait of Edward Jenner by an unknown artist. Reproduced with kind permission from the Wellcome Library.

recovered, Jenner reinoculated him with smallpox, against which Phipps showed no reaction. Phipps was subsequently inoculated with smallpox at least twenty times and Jenner concluded that he had developed protection against smallpox. Presciently, Jenner wrote: "It now becomes too manifest to admit of controversy, that the annihilation of the Small Pox, the most dreadful scourge of the human species, must be the final result of this practice." ${ }^{14}$ Although others had treated against smallpox by inoculation with cowpox, Jenner was the first to publish his findings in 1798. Jenner coined the term "vaccination" for what we know of today as the administration of an antigen to produce an immune response by producing an antibody, after the medical name for cowpox (vaccinia), and in 1891, Louis Pasteur extended the terms "vaccine" and "vaccination" to refer to the artificial induction of immunity against any infectious disease. ${ }^{15}$ In 1840 , the British government banned the use of variolation and provided the cowpox inoculation free of charge, and in 1980 the World Health Organization declared that smallpox had been globally eradicated. ${ }^{16}$ Edward Jenner died fêted, successful and wealthy.

\section{The genealogy of Edward Jenner}

Edward Jenner's family was extremely respectable. Two of his brothers were clergymen, as was his father. His grandfather's first cousin was a clergyman and president of Magdalen College, Oxford. Edward Jenner's genealogy is cited in several works, such as Fosbroke and Smyth, ${ }^{17}$ Fosbroke $^{18}$ and Burke and Burke. ${ }^{19}$ His grandfather, great-grandfather and great-great-grandfather, however, who were all bakers, had more humble origins.

In addition to Edward Jenner's pedigree, which converges on Standish in Gloucestershire, a Jenner family originates from Kempsford in Gloucestershire and surrounding villages, extending into Wiltshire, for which a fragmentary pedigree exists. ${ }^{20}$ The aim of this research was to use standard genealogical methodology and archival material to attempt to link the two families and thereby possibly extend the extant pedigree of Edward Jenner. A pedigree has been constructed that only includes connections for which a high degree of certainty exists, and most relationships have been corroborated by multiple sources. This article focuses in detail on the lineage of the Kempsford and Marston Meysey Jenners, which remains mostly unpublished, and extends that of Edward Jenner to at least 1500. It reveals that his distant cousins were extensive landowners in Gloucestershire and Wiltshire and included the MP and goldsmith Robert Jenner, and also illustrates the potential upward social mobility of the country yeoman in the sixteenth- and seventeenth-century shires. 
The pedigree of the Jenners of Berkeley from Edward Jenner's son, Robert-Fitzharding Jenner, Esq., MA, according to Burke and Burke, is:

Lineage. THE REV. STEPHEN JENNER, M.A., b. in 1702, vicar of Berkeley and Rector of Rockhampton, co. Gloucester. (son of STEPHEN JENNER, by Mary, his wife, dau. of Thomas Davies, of Moor End, and grandson of STEPHEN JENNER, of Slimbridge, who was son of STEPHEN JENNER of Standish Court, who d. in 1667) m. Sarah, dau. of the Rev. H. Head, M.A., vicar of Berkeley and Prebendary of Bristol, and d. in 1754, having had issue. $^{21}$

This is summarised in Pedigree 1 (Figure 2), with embellishments from parish records, wills and other sources. The association of Stephen Jenner (1612-1667) with Standish Court is questionable as, according to Morgan and Smith, it "was occupied by the lord of the manor, Sir Henry Winston, in 1590, by his son Henry in 1610, and by Sir Ralph Dutton in 1631 and 1634. In 1672 William Dutton lived there, and the house had 9 hearths. It was apparently let as a farm-house by $1735 .{ }^{22}$

Although Stephen may have inhabited Standish Court in the intervening years, the association probably represents an attempt by later chroniclers to aggrandise the family. In his modest will of $1667,{ }^{23}$ Stephen makes no mention of an estate. He describes himself as a baker, and divides all his goods between his wife and children equally, with his wife to have the use and control of them for the maintenance of their children as long as she remains a widow. Stephen could not sign his name and appointed his brothers Anselme and William as witnesses, and Anselme and another brother, Robert, as overseers. Stephen Jenner (1612-1667) and his eight siblings were born to Francis Ginner/Gynner and were baptised at Stonehouse, Gloucestershire, a neighbouring parish to Standish. ${ }^{24}$

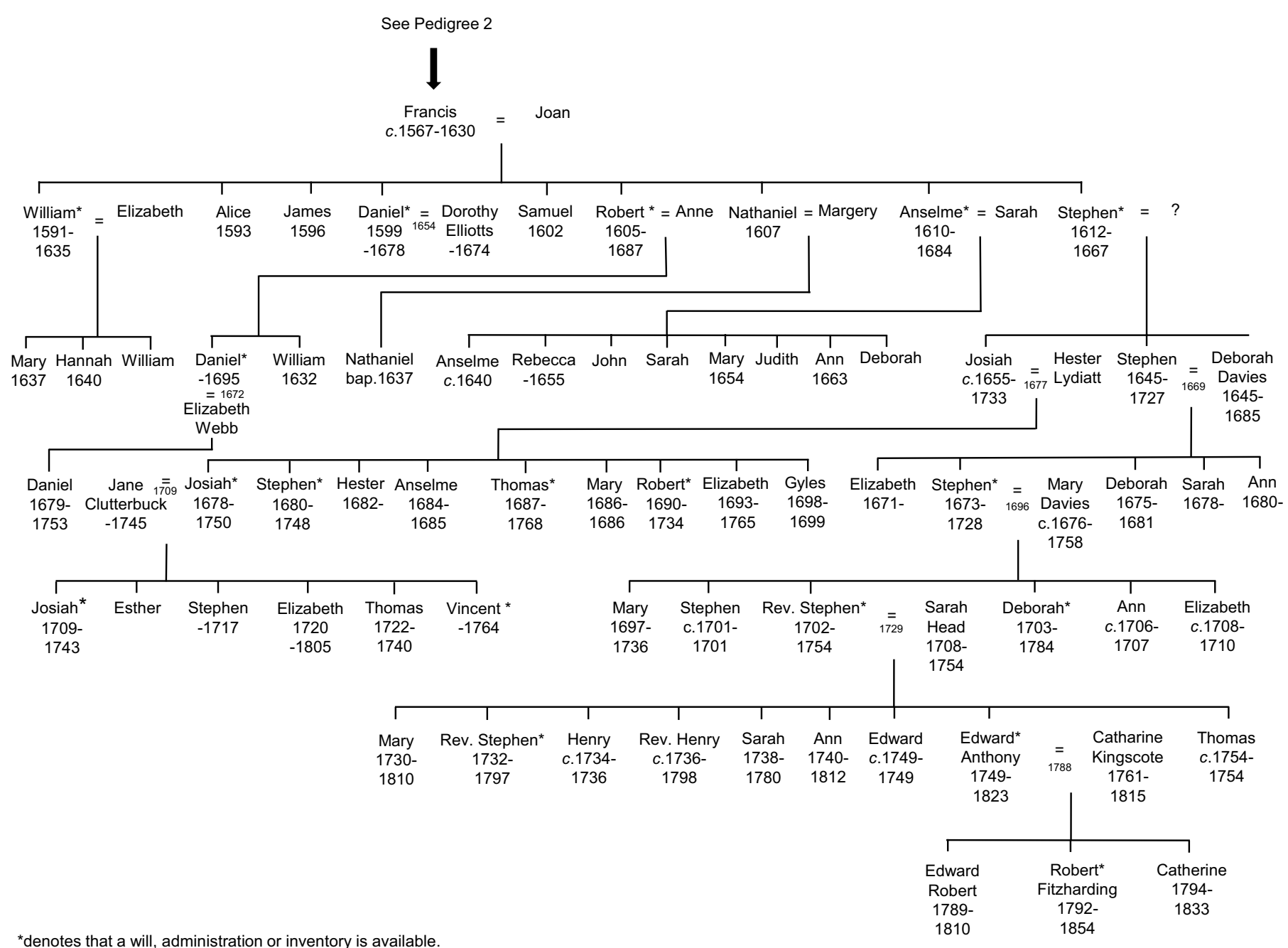

Figure 2. Pedigree 1. The family of Edward Jenner leading to Standish, Gloucestershire. 
Francis married Joan (probably Joan Bence ${ }^{25}$ ) (see Figure 2) and in his brief 1630 will, he only mentions two of his children, Nathaniel and Samuel, to whom he left $£ 10$ each. ${ }^{26}$ He left his remaining goods to his wife Joan, whom he made his executrix, and he was literate. Knowledge of the subsequent descendants of some of the offspring of Francis and Joan is patchy, due to the incompleteness of seventeenthcentury parish records, especially those of Standish during the Commonwealth period. However, four of Stephen's brothers left wills: William in $1635,{ }^{27}$ Daniel in $1678,{ }^{28}$ Anselme in $1684^{29}$ and Robert in $1687 . .^{30}$ In the resident tax lists for Stonehouse, ${ }^{31}$ William is listed as a tucker (a cleaner of cloth) and James as a tailor in 1622, both as temporarily resident sons. In 1632, Stephen is also listed as a tucker; Anselm is listed between 1658 and 1675 as a tailor/yeoman; Daniel is listed as a baker; and William is listed between 1658 and 1666 as a weaver.

Robert Jenner's son Daniel was the clerk in Pitchcombe and was baptised at Stroud St. Lawrence on 14 February $1650^{32}$ and buried in $1695 .^{33}$ His son, also Daniel, who was born on 14 February 1679 in Stroud ${ }^{34}$ and died in $1753,{ }^{35}$ became a clothier in Pitchcombe and had a flourishing family of nine children. Daniel of Stonehouse who died in 1678 mentions no children in his will and leaves bequests to his brothers and their children. ${ }^{36}$

Stephen's (1612-1688) younger son Josiah, a baker of Standish, married Hester Lydiatt, a widow from Stonehouse, in $1677 .^{37}$ One of Josiah's children, Thomas, entered Magdalen College, Oxford, in 1703, aged fifteen, was awarded degrees of BA, MA, BD and DD, and was a fellow between 1715 and $1745 .^{38}$ Additionally, he was curate of Horspath in 1721, vicar of Boldre, Hants between 1721 and 1730 , prebendary of Worcester in 1728, rector of Wickenford, Worcestershire between 1730 and 1733, and rector of Icomb from 1733 to $1768 .{ }^{39}$ He was president of Magdalen College from 1745 until his death in $1768 .{ }^{40}$ Stephen Jenner (1645-1727) married Deborah Davies on 2 May 1669 at Standish. ${ }^{41}$ His son, Stephen (1673-1728), was a baker of Slimbridge and left an estate in Berkeley to his daughter and son-in-law. ${ }^{42} \mathrm{He}$ is described as a gentleman in the records of his son Stephen at Pembroke College, Oxford, where he matriculated in 1720, obtaining his BA in 1723 and MA in $1726 .{ }^{43}$ He became rector of Rockhampton and vicar of Berkeley. ${ }^{44}$

\section{The link between the Jenners of Standish and Kempsford}

Two lines of evidence connect the Jenner family of Standish to the large Jenner family of Kempsford and environs: one is circumstantial and the other is a primary source. The circumstantial tie is a heraldic one concerning the arms of the Berkeley Jenners, which were: "Arms - Az., two swords, erect, in chev., arg., hilts and pommels, or, between three covered cups, of the last". ${ }^{45}$ Although no Jenner family is listed in the Visitations of Gloucestershire, that for Wiltshire in 1623 mentions Edith Jenner under the entry for Vaulx, as "Editha filia Will'mi Jenner de Cainsford [Kempsford] in com. Glouc." the wife of "Jacobus Vaulx de Marston Maisay in com. Wilts". ${ }^{46}$ The monument to James Vaulx and Edith in Meysey Hampton church shows her arms above her effigy, as three covered cups (Figure 3). Bigland (1792) ${ }^{47}$ acknowledges this as "three covered cups for Jenner" and the similarity between this blazon and that of the Berkeley Jenners potentially links the two families. However, the monument of Stephen Jenner who died in 1754 and his wife in Berkeley church displays the arms "Azure a cross coupée between four fleur de lys or", ${ }^{48}$ probably intended to be "Azure a cross flory between four fleur-de-lis or", which are those of Jenner/Jennour of Essex, including the baronetcy of Jenoure/Jennoyre of Much Dunmow, Essex, granted by Cooke in 1628, which become extinct in $1755 .{ }^{49}$ Whoever erected the monument probably unwittingly used these unauthorised arms.

The primary source that unambiguously connects Francis Ginner/Gynner to Kempsford is a legal case concerning a church seat, from 27 Nov $1607,{ }^{50}$ which involved Francis as a deponent and provided this information: "Deponent: Francis Ginner, tucker, of Stonehouse, where he has lived for 30 years. Born at Kempsford, aged c.40." Francis was thus born in about 1567 and possibly went to Stonehouse for his apprenticeship as a child.

The Jenner genealogy in Kempsford (Pedigree 2; Figure 4) contains two contemporaneous Francis Gynners who were first cousins, born to William Gynner (who died in 1589) ( $^{51}$ and his brother Robert (who died in 1590). ${ }^{52}$ One Francis remained in Kempsford, where his children were baptised: Kathryn (in 1589), ${ }^{53}$ Annis (Agnes) (in 1590), ${ }^{54}$ Elizabeth (in 1591) ${ }^{55}$ and Alice (in 1593). ${ }^{56}$ Robert Gynner's will in $1591^{57}$ mentions his granddaughter Kathryn, the daughter of his son Francis. Therefore, the Francis who remained in Kempsford was the son of Robert, whereas the Stonehouse Francis was the son of William. This is confirmed by a bequest in William's will in $1589^{58}$ to his son Francis Gynner of fourteen tods of wool, which Francis already had in his possession (a tod was an English weight for wool, usually weighing 28 pounds but varying around the country). As a tucker in Stonehouse, Francis would have had direct access to sell the wool to merchants and spinners in the Stroud valleys. In the 1608 muster list, Francis is listed for Stonehouse as "Francis Ginner tucker. Aged 40, lower stature."59

\section{The Jenner family of Kempsford}

The village of Kempsford lies on the edge of the Cotswolds, between Cricklade and Lechlade and about $14 \mathrm{~km}$ east of Cirencester. Marriage and birth entries in the parish records began in 1573 and burials in 1575, with a notable gap in all entries for the years 1604 to 1617 , "defective through negligence"..$^{60}$ The Jenner surname spelling variants encountered in the research, even within individual documents, include Joyner, Junar, Gynor, Gymer, Gyner, Ginner, Gener, Genner and Gynner. 


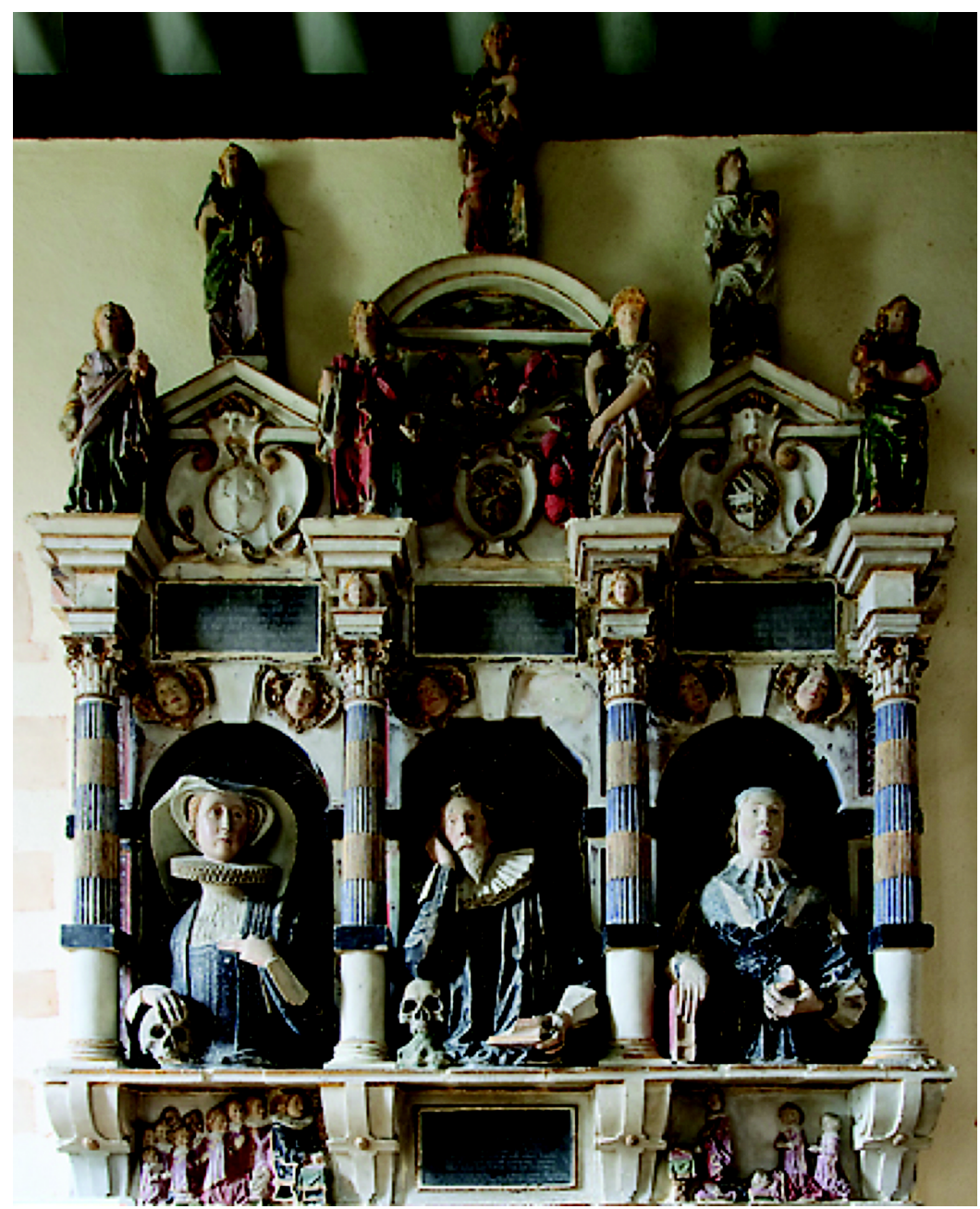

Figure 3. The monument in St. Mary's Church, Meysey Hampton, Gloucestershire, to Dr James Vaulx (d.1626) and his two wives: Edith Jenner (1576-1616) to his right, and his second wife, Philipa Horton (d.1631) to his left. Some of the children of James and Edith are depicted beneath Edith. http://www.geograph.org.uk/photo/3421710. $\odot$ Copyright Mike Searle and licensed for reuse under this Creative Commons Licence.

\section{Generation 1}

Thomas Joyner and his wife Joane are the earliest traceable Kempsford Jenner individuals and they made wills within ten days of each other in 1558. This proximity of dates suggests that both might have succumbed to disease, possibly the severe nationwide influenza epidemic of $1557 / 8$ that killed Mary Tudor. ${ }^{61}$ Evidence that Joyner is a spelling variant of Jenner is provided by five other Kempsford wills from the Gloucestershire Consistory Court that were witnessed by Thomas: that of Joan Hintley, made on 20 March 1554, witnessed by Thomas Junar ${ }^{62}$; Agnes Richins, made on 22 April 1557, witnessed by Thomas Gynor ${ }^{63}$; Walter Costerd, made on 14 September 1543, witnessed by Thomas Gynner ${ }^{64}$; Thomas Saverie, made on 10 July 1557, witnessed by Thomas Gynner ${ }^{65}$; and William Richins, made on 15 September 1551, witnessed by Thomas Gynner. ${ }^{66}$ Because only one Jenner family appears in the parish within this period, these name variants unquestionably represent the same person.

Thomas Joyner ${ }^{67}$ left $8 \mathrm{~d}$ to the church of Kempsford, 4d to the mother church of Gloucester, $6 \mathrm{~d}$ to all his godchildren and diverse legacies to other individuals of $12 \mathrm{~d}$ or $21 \mathrm{~d}$. His son Robert is not mentioned, but he left an interest in two-thirds of his estate to his son William and one-third to his wife. Joane Joyner ${ }^{68}$ left sundry household goods to her children and friends and relatives. She also left her son Robert six sheep and two silver spoons, her daughter Agnes Mathew 26s 8d and a silver spoon, her daughter Margarett Pope 26s 8d, her daughter Joan Hinton 20s and a silver spoon, $4 \mathrm{~d}$ to each of her godchildren and a sheep to each of her grandchildren. She made her sons William and Robert executors. Although the amount of money bequeathed was not large, the bequests of several silver spoons signify some status. 


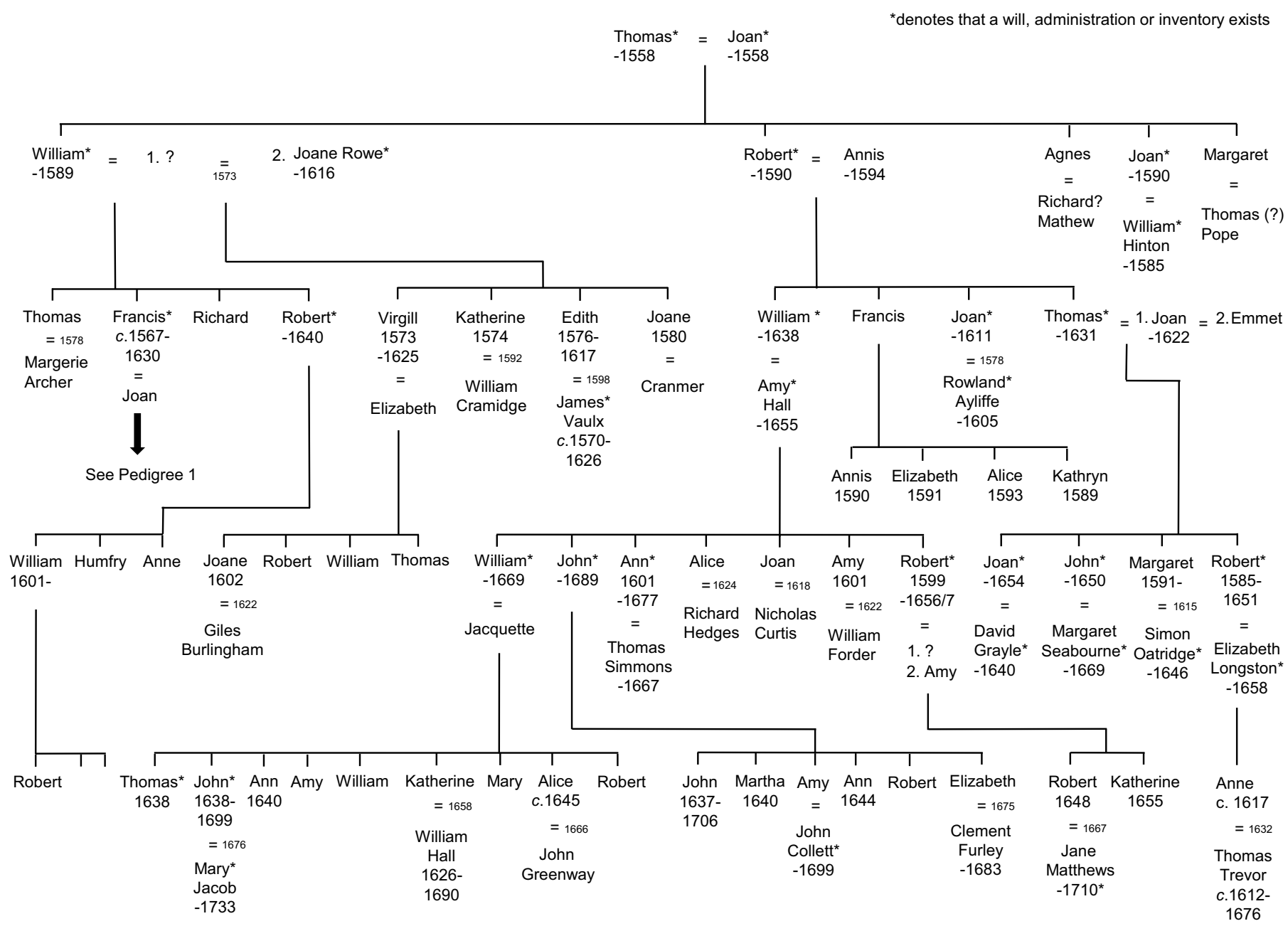

Figure 4. Pedigree 2. The Jenner family of Kempsford, Marston Meysey and Meysey Hampton, Gloucestershire.

\section{Generation 2}

The two sons of Thomas and Joane, Robert and William, each left wills. Robert Gymer/Gynner, husbandman, was buried in Kempsford on 30 December $1590 .{ }^{69}$ His pecuniary legacies totalled approximately $£ 30$ and included 20 s to the poor of Kempsford, $12 \mathrm{~d}$ to the church of Kempsford, 40 s to his son Thomas (who owed him $£ 14$ ) and 40 s to each of Thomas' sons, $£ 10$ to his daughter Joan Ayliffe and $£ 36 \mathrm{~s} 8 \mathrm{~d}$ to each of Joan's children, 20s to Katherine (the daughter of his son Francis), Johane Hewghes $2 \mathrm{~s}$, $3 \mathrm{~s}$ to each of the four overseers of his will: Humfrey Costerd, Richard Mathew, Robert Gynner and his son William Gynner. ${ }^{70}$ He was also owed 20s by Humfrey Warde. He left twenty of his forty hogs and twenty of his best sheep to his son William and also mentions three servants: Humfrey Pope, William Patrige and Margaret. He appointed Annys (his wife) and Francis (his son) executors, and the will was witnessed by Humfrey Costerd and William Gynner. The earliest Kempsford will witnessed by Robert Gynner was that of William Crippes, on 1 March $1553,{ }^{71}$ suggesting he was then already at least twentyone years old and placing his birth prior to 1532 .

William Gynner/Ginner was buried in Kempsford on 8 August $1589^{72}$ and his pecuniary legacies included 5 s to Kempsford church, 20 s to the poor of Kempsford, $5 \mathrm{~s}$ to the poor of Cricklade, $£ 100$ to each of his sons Thomas and Richard, $£ 60$ to his son Virgil, $£ 50$ to each of his daughters Katherine, Edith and Joan, $6 \mathrm{~d}$ to each godchild and 20 s to each of three overseers. ${ }^{73}$ He made Robert Gynner, his son, the sole executor. Thus, William bequeathed the huge total for an Elizabethan will of over $£ 400$. The date of William's birth is unknown, but the earliest will he witnessed among those in Kempsford was that of William Costard in 1571. ${ }^{74}$

William married his second wife, Joan Rowe, on 2 April $1573 .^{75}$ In her will in 1616, Joan's domicile is Whelford, a hamlet within Kempsford parish. ${ }^{76}$ In addition to bequests of household goods and livestock to friends and relatives, her pecuniary legacies included 20 s to her kinswoman Margarette Rowe, $£ 5$ to be divided among the children of her daughter Joane Cranmer, 20s to her daughter Edith Voasse, 10s to 
each of Edith's eight surviving children and 10s to her daughter Katherine. Joan Gynner instructs her "cousin" (here, nephew) William Gynner, together with her son-in-law James Voasse, to oversee the estate and yardland where she lives and Virgil to receive the use and benefit of the estate for his lifetime. Virgil was the sole executor, and witnesses were James, Robert and Thomas Hinton.

\section{Generation 3}

Edith Jenner (1576-1617) married James Vaulx (or Voasse) on 18 January $1598^{77}$ and they had twelve children. James belonged to an armigerous family from Cumberland ${ }^{78}$ and his memorial in Marston Meysey church erected by Francis, his eldest son, in $1630^{79}$ states that he was: "a famous Practioner in Physick and Chiurgely ... who deceased March 17, 1626, to the generall loss of the whole Countrey, the private Griefe of all his Friends, more particularly of his sorrowful Wife." At least three children of James and Edith were early settlers in Virginia, America. ${ }^{80}$ According to Blacker, "Dr. Vaulx's reputation was so great, that it is said King James I sent for him to make him his physician; but asking how he had acquired his knowledge in the healing art, whether from reading, or by observation and practice, and being answered, by practice, his Majesty replied, 'Then by my saul thou has killed mony a mon; thou shlt never practice upon me,' and so dismissed him." ${ }^{81}$

\section{William Jenner (d.1638)}

Robert's son William Jenner married Amy Hall, as confirmed by the will of her mother, also Amy Hall, ${ }^{82}$ who left her daughter "Amy Gynner" $£ 13$, and also by that of William Jenner's son Robert (in 1658), ${ }^{83}$ who appointed his cousin Robert Hall of Arlington one of his executors (he was the grandson of Amy Hall by her son Robert). William "of Dunfield", also a hamlet within Kempsford parish, was buried at Kempsford on 20 November $1638^{84}$ and his will mentions seven children. ${ }^{85}$ (They are also mentioned in the will of his wife Amy, who died in 1655. . $^{86}$ The children were: Ann, who married Thomas Simmons (Simons) ${ }^{87}$; Alice, who married Richard Hedges in Eisey, Wiltshire in $1624^{88}$; Amy, who married William Forder in Kempsford in $1622^{89}$; Joan, who married Nicholas Curtis in $1618^{90}$; William; John; and Robert. Ann and Thomas Simmons from Southrop had no issue and Ann left her entire estate to her nephew John, the son of her brother William. ${ }^{91}$

At least twelve Kempsford wills witnessed by William Gynner as clerk or vicar exist within a thirteen-year period. The earliest was that of Richard Cook, on 25 July $1580^{92}$ and the latest was that of John Bristow on 4 December $1593 .{ }^{93}$ Robert Watte, Clerke, witnessed the will of Robert Hewer of Kempsford, on 27 March $1597 .{ }^{94}$ As the earliest William Gynner in Pedigree 2 died in 1589, the William Gynner who was curate until at least 1593 must have been William Gynner who died in 1638. This is supported by the bequest to William in 1590 by his father, Robert Gynner, of his barley lying in the vicarage barn, which suggests that Robert was storing his grain in his son's barn. ${ }^{95}$ The advowson of the parish was in the hands of Gloucester Cathedral from 1541, ${ }^{96}$ but early ecclesiastical records are patchy. According to Mynors, ${ }^{97}$ John Brooke was vicar in 1578 and Henry Blackborne in 1597; thus, signatories to Kempsford wills reveal two previously unknown incumbents between 1580 and 1597: William Gynner and Robert Watte.

The forty-one Kempsford men listed as fit for fighting in 1608 include:

Frauncis Gynner. Aged 40. tallest stature. trained.

Robert Gyner unable in body has one corslet furnished.

Frauncis Gyner and William Gyner have between them one caliver furnished. ${ }^{98}$

\section{Joan Gynner (d.1611)}

Robert's daughter Joan Gynner married Rowland Ayliffe in Kempsford on 2 July $1578^{99}$ and they lived in Sherston Magna, Wiltshire. Rowland's will of $1606^{100}$ is in accordance with that of Robert Gynner who died in 1590: he left each of his three children (Robert, John and Margaret) $£ 10$ each, money that he says was mostly left to them by the will of "Roberte Gynner", their grandfather, and "Annis Gynner", their grandmother, and also by their uncle, "John Allife". He mentions his son-in-law William Clarke and his two children. His wife is made executrix and his brother Edward Ailife and his wife's brothers, Thomas and William Gynner, are overseers. The administration of Joan's estate in $1611^{101}$ was granted to Robert Ailiffe, the vicar of Sherston Magna, Richard Woodroffe and Thomas Gynner.

\section{Thomas Gynner (d.1631)}

The will of Robert's son Thomas Gynner, yeoman, of Milborne in the parish of Malmesbury, Wiltshire in 1631 was rather modest. ${ }^{102}$ His possessions were appraised to be worth $£ 38$. His largest bequest was $£ 30$ to his daughter Margaret Oatridge and her children, to be divided between them equally. Thomas was illiterate and signed with his mark.

\section{Generation 4}

Thomas Gynner's four children were all remarkably successful, either in business or in marriage. Margaret Jenner was baptised in $1591^{103}$ and married Simon Oatridge of Garsdon, Wiltshire in $1615 .{ }^{104}$ He belonged to the armigerous Oatridge family of Butler's Court, Lechlade. ${ }^{105} \mathrm{~A}$ 
Herald Visitation pedigree erroneously states that Simon's wife was Jane Jenner, but the genealogical evidence from Thomas's will in 1631 confirms that his wife was Margaret. ${ }^{106}$

John Jenner died in $1650 .^{107}$ He had married Margaret Seabourne, the daughter of John Seabourne alias Plummer, yeoman of Sherston Magna, Wiltshire. ${ }^{108}$ Both John and Margaret died in Crudwell, Wiltshire (Margaret in 1669). ${ }^{109}$ In his will, in the absence of issue, John left the residue of his estate to his brother-in-law Henry Ottrig, and appointed his brother Robert Jenner one of his overseers. ${ }^{110}$

Joan Jenner married David Grayle and died in $1654 .{ }^{111}$ Her husband died in $1640 .{ }^{112}$ A messuage in Garsdon, Wiltshire was leased in 1616 from Sir Henry Moody to John and Thomas Gymer to be held following the death of David Grayle and his wife Joan. ${ }^{13}$ Joan and David had a son Robert, who co-leased a messuage with his father in $1627,{ }^{114}$ and two daughters, Margery and Elizabeth. ${ }^{115}$ Joan was buried in Malmesbury Abbey, and her will was proved in $1655 .^{116}$

Robert (1585-1651) was the most successful of Thomas's children. He married Elizabeth Longston, the daughter of Thomas Longston of London, grocer. ${ }^{17}$ She died in $1658 .{ }^{118}$ Robert and Elizabeth had one daughter, Anne, who at the age of fifteen married Thomas Trevor, Esq. in 1632, the son and heir of Sir Thomas Trevor, knight, Lord Baron of the Exchequer. ${ }^{119}$ Anne died without issue and Thomas married Mary, daughter of Samuel Hortrey of Kew. ${ }^{120}$ Thomas was created a Knight of the Bath at the coronation of Charles II and baronet of Enfield, Middlesex in 1641. He was MP for Monmouth in 1640 and MP for Tregony, Cornwall in 1647 and died in $1676 .{ }^{121}$ Robert's position in the pedigree is confirmed by two sources. According to Sadler:

Robert Jenner being minded to settle his estate so that it should remain in his name and blood ... did by indenture of 20th May, 1643 , between himself and John Jenner, of Marston Mesey, in consideration of his natural affection to the said John Jenner the elder, "his cousin German," and to John Jenner, his son, and William Jenner and Robert Jenner, the younger, brothers of John Jenner, the elder. ${ }^{122}$

As Robert was the first cousin of John, William and Robert, then Robert's father Thomas is the Thomas mentioned in the will of Robert (1590). ${ }^{123}$ Furthermore, a court case states that Daniel Oatridge (son of Simon) seized part of the manor of Widhill due to the non-payment of a loan of $£ 500$ and rented it to Henry Morgan, and also states that Daniel and John Jenner Esq. are second cousins. ${ }^{124}$ Robert made his fortune as a goldsmith in London: he became a freeman of the London Goldsmiths' Company in 1613, following an apprenticeship under Edward Greene, ${ }^{125}$ and he specialised in refining imported silver bullion used in the wire-drawing trade. Much is known about his career in precious metals, and he purchased a house in Foster Lane, London for $£ 1400 .{ }^{126}$ He became MP for Cricklade in 1628 until 1629 and in 1640 in the Short Parliament and again in the Long Parliament until $1648 .{ }^{127}$ Robert was a supporter of Parliament, but a moderate one, and he was secluded at Pride's Purge in $1648 .{ }^{128}$ Robert bought several estates in Gloucestershire and Wiltshire, including the manor of Eisey, Gloucestershire, which he bought from Sir John Hungerford and his son Anthony in about 1628 together with his brother John of Crudwell and William Gibbs, goldsmith of London. He resold it in $1630 .{ }^{129}$ He also bought the manor of Widhill in Wiltshire in $1624^{130}$ and in February $1647 / 8$ purchased the manor of Marston Meysey, Wiltshire, for $£ 109212 \mathrm{~s} 91 / 2 \mathrm{~d}$ from the trustees of Parliament who had confiscated the manor from the Crown during the Civil War. ${ }^{131}$ Following petitioning of the inhabitants of Marston Meysey, the Lords' Journal for 1648 notes the building of a new church in lieu of an old and ruined chapel of ease. ${ }^{132}$ The gift of a silver chalice to the church of St. James, Marston Meysey, inscribed "This Church was built and this Cupp given by Robert Jenner Esq .- 1648", shows that the chapel was built at Robert's expense. ${ }^{133}$ It was the only chapel to be built during the Commonwealth and Robert revived a claim to the advowson. ${ }^{134}$ Cricklade church contains memorials to Robert and his wife Elizabeth, and that of Robert attests to his munificence and benefaction:

Here lyeth the Body of Robert Jennor, Esq. Citizen and Gouldsmith of London, who, out of his Piety \& Charetie, Built the Eight Almeshouses in the Abbie of Malmsburie, And hath Allowed Fourtie Poundes Ayear for Ever for the Maintenance of Them: who Allsoe Built a free schoule in this Parrish \& Left Twentie Poundes A yeare for the Maintenance of it for ever. Hee Lykewise Built the Parrish Church of Marston Maysie, in the Countie of Wilts: at his owne Proper Cost and Charge: Hee Hath Allsoe given Twentie Poundes Ayeare to St. Bartholemeues Gouhlsmiths for fiveteene of the Poorest Men of Theire Companie, and five Poundes A yeare to the poore of St. John Zacharies Parrish, \& five poundes Ayeare To the Poore of St. Leonards Parrish, in Foster Lane London: being All for ever. Hee Deseased this Life the $7^{\text {th }}$ of December 1651 Aged 67 years. ${ }^{135}$

\section{William Jenner (d.1669) and descendants}

William's children are mentioned in his 1670 will $^{136}$ and those of his mother (who died in 1655) (137 $^{13}$ and mother-in-law, Alice Jaques/Jaquette/ Jakett (who died in 1648). ${ }^{138}$ His daughter Katherine married William Hall of Arlington (her second cousin) ${ }^{139}$ and his daughter Alice married John Greenway of Cirencester. ${ }^{140}$ Thomas Jenner (born in 1637) was William's eldest son. ${ }^{141}$ Thomas Jenner, gent., widower, married Elizabeth Rance in $1671 .{ }^{142}$ His first wife was possibly Marie, who was buried on 19 August 1670 at Meysey Hampton. ${ }^{143}$ Thomas and Elizabeth had three children. The first, John, was baptised in $1672^{144}$ and married Beata Stephens in $1706 .{ }^{145}$ Robert was baptised in $1675^{146}$ and Elizabeth was baptised in $1679 .^{147}$ 
William's second oldest son John (1637-1699) married Mary Jacob, the daughter of John Jacob, at Inglesham, Wiltshire on 1675 . $^{148}$ In his will, ${ }^{149}$ William mentions his son John's father-in-law, Mr Jones, suggesting that John was possibly previously married. Confirmation that John who died in 1699 was the son of William is supported by a reference in John's will in 1700 to "my cozen John Jenner Esq.", i.e., John Jenner of Widhill (1637-1706). ${ }^{150}$

No further biographical information is known for William's son William. In 1665, William Jenner gent. of Marston appointed Robert Jenner (1643-1724) rector of Lydiard Millicent in Wiltshire. ${ }^{151}$ The advowson belonged to the Richmond family as lords of Lydiard Millicent manor, but they were suspected of recusancy and the presentations between 1603 and 1724 were made by trustees or grantees. ${ }^{152}$ Robert matriculated at Magdalen Hall in 1651 and was rector of Churchlench (1663-1670) and rector of Lydiard Millicent until his death in $1724 .{ }^{153}$ According to his tombstone in Lydiard Millicent church, Robert was aged eighty-eight at his death, which would place his birth in about $1636 .{ }^{154}$ It is unclear whether this Robert Jenner is the son of William who died in 1770, because his estimated birth precedes that of his older brothers, and another William who left a will in 1690 was also resident in Meysey Hampton at the time. ${ }^{155}$

\section{John Jenner (d.c.1689) and descendants}

John Jenner was a yeoman of Fifield, Oxfordshire. He left his son John a shilling in his will of $1690^{156}$ and mentions his daughter Amy Collett and two of her children, John Collett, yeoman of Westcote, Gloucestershire (who died in 1698) ${ }^{157}$ and Walter Collet (baptised in 1670). ${ }^{158}$ Two other daughters are mentioned: Elizabeth, who was born in about 1651 and married Clement Furley ${ }^{159}$ who died in 1683 , ${ }^{160}$ and Anne.

\section{Robert Jenner (d.c.1658) and descendants}

Robert was probably married more than once, as evidenced by a reference to "Amy my wife that now is" in his will. ${ }^{161}$ Robert left freehold land in South Cerney to his son Robert, and the use of $£ 200$ until he attained sixteen years. He had already made over his land in Marston to his wife Amy as her jointure. He made his wife Amy executrix and his brother William, his cousin Robert Hall of Arlington, and his two brothers-inlaw (Thomas Simons of Southrop and Nicholas Curtis of Kempsford) his overseers. Robert signed with a mark. A Katherine Jenner was baptised at Kempsford on 21 May 1655, daughter of Robert and Amy Jenner. ${ }^{162}$ As Robert's will was made on 9 April 1656 and he states that his son Robert is his only son and heir, Amy presumably died in infancy. Robert's son Robert married Jane Mathews of South Cerney in 1667 when aged nineteen, which places his birth in about $1648 .{ }^{163}$ He was possibly the Robert Jenner from Dunfield who was buried in $1688,{ }^{164}$ as Jane Jenner died intestate in 1710 and her administration states that she is a widow of Dunfield. ${ }^{165}$

\section{The manor of Widhill}

Robert Jenner who died in 1651 bequeathed Widhill Manor and its rents to his wife Elizabeth for life and its lease to his nephew Henry Oatridge for the annual rent of $£ 450$ until 25 March 1660, with the option for renewal. ${ }^{166} \mathrm{He}$ also gave John Jenner (1637-1706) the right to present a minister to Marston Meysey as often as it should become void. John Jenner (1638-1706), who was stated to be the younger son of John Jenner of Marston Meysey in Robert Jenner's 1651 will, inherited the manor of Widhill whilst a minor. John matriculated at Magdalen Hall, Oxford in 1653 and graduated with a BA in 1655/6 and MA in 1658. However, he subsequently "got into difficulties so great that the property became the subject of many lawsuits, from 1684" ${ }^{167}$ Due to his debts, John absconded in 1680 or 1681 and was outlawed for debt in 1682. His estate was forfeited to the Crown and the profits were diverted to his creditors. ${ }^{168}$ Bishop Narcissus Marsh, who was a fellow student and friend of John's at Oxford, claims in his biography to have lent John the huge sum of $£ 2000$ towards his debts. ${ }^{169}$ Deborah Culme of Midghall also lent $£ 100$ to John Jenner of Widhill, esq., Ephroditus Marsh of Hammersmith, Middlesex, gent. and Narcissus Marsh (in 1669) and $£ 100$ to Robert Jenner, Rector of Lydiard Millicent and John Jenner of Widhill, Esq. (in 1675). ${ }^{170}$ Exactly why the estate generated such debts is unclear. John's son Nathaniel who died in $1732^{171}$ was apprenticed to William Whitmay of London for seven years in $1685^{172}$ and recovered the Widhill estate that had been seized by creditors following his father's death in 1707. ${ }^{173}$ Nathaniel married Katherine Adee (Adey) in 1707 at Earl-Stoke, Wiltshire. ${ }^{174}$ Of their five children, Margaret died young, Robert died in 1730, aged eighteen, ${ }^{175}$ and John, who entered Lincoln's Inn in 1725 and is described as an armiger, ${ }^{176}$ died in 1731, aged twenty-three. ${ }^{177}$ Nathaniel's son, also Nathaniel, married Catherine Parker of Lisshill (1729-1767) in 1748 ${ }^{178}$ and a daughter Mary was baptised in $1761 .{ }^{179}$ Nathaniel died in $1761,{ }^{180}$ and in his will that was proved on 14 April 1764 he left all his property to Edward Pleydell, Esq., and Richard Kinneir, both of Cricklade, in trust to pay all his and his father's debts and the residue to his kinsman, Adye Baldwin, of Slough, Buckinghamshire. ${ }^{181}$ The estate was again subjected to lawsuits, which were settled by the Court of Chancery in 1766 , and on 9 March 1769 the manor was sold to Jacob, Viscount Folkestone, grandson of Sir Mark Stewart Pleydell, of Coleshill, for $£ 18,600$. ${ }^{182}$

\section{The manor of Marston Meysey}

Robert Jenner bequeathed Marston Meysey Manor to Robert Jenner, his godson, the son of William Jenner of Marston Meysey, also known as William Jenner the elder. ${ }^{183}$ In 1669, a survey of Marston Meysey Manor by the Bishop of Gloucester showed that members of the Jenner family held a 2-yardland freehold, and five other copyhold properties in Marston Meysey as tenants, totalling a further $81 / 4$ yardlands (in Marston Meysey at this time, a yardland was 25 acres). ${ }^{184}$ After the Restoration, Marston Meysey Manor reverted to the bishops of Salisbury, ${ }^{185}$ but in 1699, John Jenner, the son of William who died in 1669, left his wife the wood in the orchard that belonged to his manor house of 
Marston. ${ }^{186}$ This house appears to be Marston Manor Farm, which had been leased by the Jenner family since about 1621 and in 1669 consisted of 183 acres of arable land. ${ }^{187}$ For the baptism of two of his children, John is described as "of Marston manor farm". ${ }^{188,189}$ John's oldest son and heir, also John (1682-1716), inherited the estate. In 1717, in addition to the parsonage, tithes and copyhold estate in Southrop, John left Marston Meysey Farm to his brother Robert. ${ }^{190}$ On Robert's death in 1743, the estate passed to his son John and to John's spinster daughter and heir Mary (1762-1826). ${ }^{191}$ John died in $1788,{ }^{192}$ and Mary sold the Southrop rectory in 1802 to John Tuckwell who died in $1826^{193}$ and left the residue of her Marston Meysey estate to David Archer. ${ }^{194}$ In the seventeenth and eighteenth centuries, the Jenners were influential in the community as parish officers, tax collectors and assessors, and some members of the family styled themselves gentlemen and were considered minor gentry. ${ }^{195}$

\section{John Gynnor, a fifteenth-century Gloucestershire Jenner and connection to Jenners of Suffolk}

Sir Francis Fust, Bart. (1705-1769) of Hill Court, Gloucestershire, "always acknowledged Edward Jenner of Berkeley to be a relation", ${ }^{196}$ which seems unlikely, considering that he died when Edward Jenner was only twenty, but Sir Francis descended from the Jenners of Wenvoe Castle, near Cardiff, who bore the same arms as the Berkeley Jenners. ${ }^{197}$ The Wenvoe Jenners trace their ancestry back to Sir Thomas Jenner of Petersham, Surrey (1638-1707), ${ }^{198}$ who was the son of Thomas Jenner of Mayfield, Sussex and Dorothy (née Glyde). ${ }^{199}$ He entered the Inner Temple and was called to the Bar, married Ann Poe in $1661,{ }^{200}$ was knighted in 1683 and became MP for Rye, Sussex for $1685-1686 .{ }^{201}$ He was also Baron of the Exchequer, Recorder of London, 1683-1686 and King's Serjeant, $1684 .{ }^{202}$ He was arrested while attempting to escape with James II and was sent to the Tower, but continued to work as a barrister after his release in $1690 .{ }^{203}$ Sir Thomas's arms were augmented in 1684 to become "az. two swords, erect, in chev. ar. hilts and pomels or, betw. three covered cups of the last. - Crest, a covered cup or, standing betw. two swords, in saltier, ar. hilts and pomels of the first". ${ }^{204}$ Thomas belonged to a dispersed Sussex yeoman family. His grandfather was Thomas Jenner of Northam, Sussex, who died in about $1640 .{ }^{205}$ The origin of the arms that were augmented is unknown and requires further research at the College of Arms in London, but may show that the Jenners of Kempsford and those of Sussex are connected.

Some Joyner individuals were recorded in Cirencester from 1560, ${ }^{*}$ and a cluster of sixteenth- and seventeenth-century Joyners/Jenners at Shrivenham, Oxfordshire, near the Wiltshire border and not far from Kempsford, include a baptism in $1575^{206}$ but there were no other major local concentrations of Jenners or name derivatives in the sixteenth century. However, detailed information for John Gynnor alias Chynnor from the fifteenth century almost certainly implicates him as an antecedent of the Jenners from Kempsford and Marston Meysey. According to Winchester College records, John Gynnor was admitted in 1434, as "de Castell Eton [Castle Eaton] in com. Wilts" 207 and then became a fellow of New College, Oxford, in 1441, as "de par. de Heyworth [Highworth], Sar. dioc". ${ }^{208}$ He was then admitted as a Fellow of Winchester College in 1452 , as "de parochia de Eton Meysey in com. Wilch"209 and then became chaplain of Fromond's Chantry at Winchester between 1461 and 1492, when he died. This establishes a connection between the Jenner family in the Marston Meysey area to the early fifteenth century and also suggests a degree of social standing and education.

\section{Conclusion}

Diverse archival sources have linked the pedigree of Edward Jenner to the Jenner family of Kempsford and environs, which contains important Gloucestershire landowners and extends to at least the start of the 1500s. The key importance of court depositions in providing locational data and in linking collateral family branches is highlighted, as well as the importance of wills in establishing early genealogy prior to the start of parish registers. The research integrates two individuals whose exact positions were unknown into the broader Jenner genealogy: the goldsmith Robert Jenner (1585-1651), and Edith Vaulx (née Jenner, 1576-1617), about whose memorial in Meysey Hampton church much has been written. The biographies of several individuals in the Jenner pedigree demonstrate the relative potential ease for social and financial upwards mobility in seventeenth-century England. For example, Robert Jenner the goldsmith (1585-1651), who became a wealthy landowner whose daughter married a presumptive baronet, and the Rev. Thomas Jenner (1687-1768), the president of Magdalen College, Oxford, were both born into yeoman backgrounds. The connection of the Jenner family to the Marston Meysey area in the early fifteenth century via John Gynnor, the chaplain of Fromond's chantry in Winchester College, confirms that Edward Jenner truly was a child of Gloucestershire.

\section{Citation information}

Cite this article as: Chandler, John William (2018) The early genealogy of Edward Jenner and the Jenner family of Kempsford, Marston Meysey and Meysey Hampton. Journal of Genealogy and Family History. 2(1). pp. 21-35. http://dx.doi.org/10.24240/23992964.2017.1234513

\section{References}

1. Baxby, Derrick. (2004) 'Jenner, Edward'. In: Oxford Dictionary of National Biography. Oxford: Oxford University Press. http://www.oxforddnb.com/view/10.1093.

2. Baxby, Derrick. (2004) 'Jenner, Edward'. In: Oxford Dictionary of National Biography. Oxford: Oxford University Press. http://www.oxforddnb.com/view/10.1093.
3. BBC (2002) BBC TWO reveals the nation's top 100 Greatest Britons of all time. http://www. bbc.co.uk/pressoffice/pressreleases/stories/2002/08_august/21/100_britons.shtml.

4. Jenner Institute (2017) About Edward Jenner. http://www.jenner.ac.uk/edwardjenner.

5. Jenner Institute (2017) About Edward Jenner. http://www.jenner.ac.uk/edwardjenner.

6. Baxby, Derrick. (2004) 'Jenner, Edward'. In: Oxford Dictionary of National Biography. Oxford: Oxford University Press. http://www.oxforddnb.com/view/10.1093.

7. Baxby, Derrick. (2004) 'Jenner, Edward'. In: Oxford Dictionary of National Biography Oxford: Oxford University Press. http://www.oxforddnb.com/view/10.1093.

*See Gloucestershire, England, Church of England Baptisms, Marriages and Burials, 1538-1813 results for Joyner. http://www.ancestry.co.uk/. 
8. Jenner Institute (2017) About Edward Jenner. http://www.jenner.ac.uk/edwardjenner.

9. Baron, John. (1838) The life of Edward Jenner. London: Henry Colburn. p. 454

10. Jenner Institute (2017) About Edward Jenner. http://www.jenner.ac.uk/edwardjenner.

11. Morgan, A. J. and Parker, S. (2007) Translational mini-review series on vaccines: the Edward Jenner Museum and the history of vaccination. Clinical and Experimental Immunology. 147. pp. 389-94.

12. NIH U.S. National Library of Medicine (2002) Smallpox: a great and terrible scourge. https://www.nlm.nih.gov/exhibition/smallpox/sp_variolation.html.

13. NIH U.S. RMedicine (2002) Smallpox: a great and terrible scourge. https://www.nlm. nih.gov/exhibition/smallpox/sp_variolation.htm

14. Jenner, E. (1801) The origin of vaccine inoculation. London: Shury. Cited by: Miller, M, Barrett, S. and Henderson. D. A. (2006) 'Control and eradication'. In: Jamison, D. T. Breman, J. G., Measham, A. R., et al., eds. Disease control priorities in developing countries. $2^{\text {nd }}$ ed. Washington DC: International Bank for Reconstruction and Development/World Bank

15. Ullmann, Agnes. (2017) 'Louis Pasteur: French chemist and microbiologist'. In: Encyclopaedia Britannica. https://www.britannica.com/biography/Louis-Pasteur/ Vaccine-development.

16. Jenner Institute (2017) About Edward Jenner. http://www.jenner.ac.uk/edward jenner.

17. Fosbroke, T. D. and Smyth, J. (1821) Berkeley manuscripts: abstracts and extracts of Smyth's lives of the Berkeleys, illustrative of ancient manners and the constitution; including all the pedigrees in that ancient manuscript. To which are annexed a copious history of the castle and parish of Berkeley, consisting of matter never before published; and biographical anecdotes of Dr. Jenner his interviews with the Emperor of Russia, \&c. London: J. Nichols.

18. Fosbroke, T. D. (1807) Abstracts of records and manuscripts respecting the county of Gloucester; formed into a history. Correcting the very erroneous accounts and supplying numerous deficiencies in Sir. Rob. Atkins, and subsequent writers. Gloucester: J. Harris. pp. $44-46$

19. Burke, J. and Burke, J. B. (1846) A genealogical and heraldic dictionary of the landed gentry of Great Britain \& Ireland. London: Henry Colburn.

20. Sherwood, G., ed. (1911) The pedigree register (1910-1913). Vol. 2. Strand, London: G. Sherwood. pp. 154-155. https://archive.org/details/pedigreeregister02sociuoft.

21. Burke, J. and Burke, J. B. (1846) A genealogical and heraldic dictionary of the landed gentry of Great Britain \& Ireland. London: Henry Colburn.

22. Morgan, K. and Smith, B. S. (1972) 'Standish: manors and other estates'. In: Elrington, C. R., Herbert, N. M. and Pugh, R. B., eds. A history of the county of Gloucester. Vol. 10. London: Victoria County History. pp. 233-36. http://www.britishhistory.ac.uk/vch/glos/vol10/pp233-236.

23. Testamentary records. England. 1668. JENNER, Stephen. Will. Collection: Gloucestershire, England, Wills and Inventories, 1541-1858. 1668/181. http:// www.ancestry.co.uk/

24. Baptisms (PR) England. Stonehouse, Gloucestershire. 13 September 1612. GYNNER Stephen. Collection: Gloucestershire, England, Select Births and Christenings, 1538 1975. http://www.ancestry.co.uk./

25. Hudson, J. (1998) Residence and kinship in a clothing community: Stonehouse 15581804. Ph.D. thesis, University of Bristol. https://core.ac.uk/download/pdf/33133261.pdf.

26. Testamentary records. England. 1630. GYNNER, Francis. Will. Collection: Gloucestershire, England, Wills and Inventories, 1541-1858. 1630/37. http://www. ancestry.co.uk/.

27. Testamentary records. England. 1635. JENNER, William. Will Collection: Gloucestershire, England, Wills and Inventories, 1541-1858. 1635/175. http:// www.ancestry.co.uk/.

28. Testamentary records. England. 1678. JENNER Daniel. Will. Collection: Gloucestershire, England, Wills and Inventories, 1541-1858. 1678/15. http://www. ancestry.co.uk/.

29. Testamentary records. England. 1684. JENNER, Anselm. Will. Collection: Gloucestershire, England, Wills and Inventories, 1541-1858. 1684/230. http:// www.ancestry.co.uk/.

30. Testamentary records. England. 1687. JENNER, Robert. Will. Collection: Gloucestershire, England, Wills and Inventories, 1541-1858. 1687/186. http:// www.ancestry.co.uk/.

31. Hudson, J. (1998) Residence and kinship in a clothing community: Stonehouse 1558 1804. Ph.D. thesis, University of Bristol. https://core.ac.uk/download/pdf/33133261.pdf.

32. Baptisms (PR) England. Stroud, Gloucestershire. 14 February 1650. JENNER, Daniel. P320 IN 1/1. Collection: Gloucestershire, England, Church of England Baptisms, Marriages and Burials, 1538-1813. http://www.ancestry.co.uk/.
33. Testamentary records. England. 1695. JENNER, Daniel. Will. Collection: Gloucestershire, England, Wills and Inventories, 1541-1858. 1695/129. http:// www.ancestry.co.uk/.

34. Baptisms (PR) England. Stroud, Gloucestershire. 27 February 1679. JENNER, Daniel. P320 IN 1/1. Collection: Gloucestershire, England, Church of England Baptisms, Marriages and Burials, 1538-1813. http://www.ancestry.co.uk/.

35. Burials (PR) England. Pitchcombe, Gloucestershire. 10 October 1753. JENNER, Daniel. Source reference GDRN1/183. Collection: Gloucestershire, England, Church of England Baptisms, Marriages and Burials, 1538-1813. http://www.ancestry.co.uk/.

36. Testamentary records. England. 1678. JENNER, Daniel. Will. Collection: Gloucestershire, England, Wills and Inventories, 1541-1858. 1678/15. http://www. ancestry.co.uk/.

37. Frith, Brian, ed. (1954) Gloucestershire Marriage Allegations. Vol. 1. Bristol: Bristol and Gloucestershire Archaeological Society.

38. Foster, Joseph, ed. (1891) 'Jablonski-Juxston'. In: Alumni Oxonienses 1500-1714. Oxford: University of Oxford. pp. 793-836. http://www.british-history.ac.uk/ alumni-oxon/1500-1714/pp793-836.

39. Foster, Joseph, ed. (1891) 'Jablonski-Juxston'. In: Alumni Oxonienses 1500-1714. Oxford: University of Oxford. pp. 793-836. http://www.british-history.ac.uk/ alumni-oxon/1500-1714/pp793-836.

40. Magdalen College, University of Oxford. The 42 presidents. http://www.magd.ox.ac. uk/discover-magdalen/history-of-college/the-42-presidents/.

41. Marriages (PR) England. Standish, Gloucestershire. 2 May 1669. JENNER, Stephen and DAVIS, Deborah. Source reference: GDR/V1/223. Collection: Gloucestershire, England, Church of England Baptisms, Marriages and Burials, 1538-1813. http:// www.ancestry.co.uk/.

42. Testamentary records. England. 1728. JENNER, Stephen. Will. Collection: Gloucestershire, England, Wills and Inventories, 1541-1858. 1728/323. http:// www.ancestry.co.uk/.

43. Foster, Joseph. (1888) Alumni Oxonienses: the members of the University of Oxford, 1715-1886. Vol. 2. Oxford: University of Oxford. p. 750. https://archive.org/details/ alumnioxonienses02univuoft.

44. Foster, Joseph. (1888) Alumni Oxonienses: the members of the University of Oxford, 1715-1886. Vol. 2. Oxford: University of Oxford. p. 750. https://archive.org/details/ alumnioxonienses02univuoft.

45. Burke, J. and Burke, J. B. (1846) A genealogical and heraldic dictionary of the landed gentry of Great Britain \& Ireland. London: Henry Colburn.

46. Saint-George, Henry. (1882) The visitation of Wiltshire 1623. London: George Bell. p. 17. https://archive.org/details/visitationofwilt00sainrich

47. Bigland, R. (1792) Historical, monumental and genealogical collections relative to the county of Gloucester; printed from the original papers of the late Ralph Bigland Esq. Garter Principal King of Arms. Vol. 2. London: John Nichols.

48. Bigland, R. (1791) Historical, monumental and genealogical collections relative to the county of Gloucester; printed from the original papers of the late Ralph Bigland Esa. Garter Principal King of Arms. Vol. 1. London: John Nichols.

49. Papworth, J. W. (1874) Ordinary of British armorials. London: T. Richards.

50. Diocesan Archives, Gloucestershire, England. Case: Batha Gibbe vs. Giles Bennett: Church seat. 27 Nov 1607. Collection: Gloucestershire Archives, Diocese of Gloucester Collection 1541-2006. GDR/100/page 402. http://ww3.gloucestershire. gov.uk/CalmView/Record.aspx?src=CalmView.Catalog\&id=GDR\%2f1.

51. Burials (PR) England. Kempsford, Gloucestershire. 8 August 1589. GYNNER, William. Source reference P189 IN 1/1. Collection: Gloucestershire, England, Church of England Baptisms, Marriages and Burials, 1538-1813. http://www. ancestry.co.uk/

52. Burials (PR) England. Kempsford, Gloucestershire. 30 December 1590. GYNNER Robert. Source reference P189 IN 1/1. Collection: Gloucestershire, England, Church of England Baptisms, Marriages and Burials, 1538-1813. http://www.ances try.co.uk/.

53. Baptisms (PR) England. Stroud, Gloucestershire. 23 August 1589. GYNNER, Kathryn FHL film no. 956946. Collection: Gloucestershire, England, Select Births and Christenings, 1538-1975. http://www.ancestry.co.uk/.

54. Baptisms (PR) England. Stroud, Gloucestershire. 29 JANUARY 1590. GYNNER, Annis. FHL film no. 956946. Collection: Gloucestershire, England, Select Births and Christenings, 1538-1975. http://www.ancestry.co.uk/.

55. Baptisms (PR) England. Stroud, Gloucestershire. 1 March 1591. GYNNER, Elizabeth FHL film no. 956946. Collection: Gloucestershire, England, Select Births and Christenings, 1538-1975. http://www.ancestry.co.uk/.

56. Baptisms (PR) England. Storud, Gloucestershire. 22 February 1593. GYNNER, Alice. FHL film no. 956946. Collection: Gloucestershire, England, Select Births and Christenings, 1538-1975. http://www.ancestry.co.uk/. 
57. Testamentary records. England. 10 June 1591. GYMER, Robert. Will. Prerogative Court of Canterbury: Will Registers. PROB 11/77/494. The National Archives, Kew, England.

58. Testamentary records. England. 12 December 1589. GINNER or GYNNER, William. Will. Prerogative Court of Canterbury: Will Registers. PROB 11/74/528. The National Archives, Kew, England.

59. Coaley.net. Men \& armour for Gloucestershire in 1608. http://coaley.net/glos1608/ index.php.

60. Mynors, Rev. A. B. Kempsford. http://www.kempsford.net/history/pdf/history-of kempsford.pdf.

61. Williams, Brian. (1997) Infectious diseases in history: a guide to causes and effects. http://urbanrim.org.uk/diseases.htm\#influenza.

62. Testamentary records. England. 1556. HINTLEY, Joan. Will. Collection: Gloucestershire, England, Wills and Inventories, 1541-1858. 1556/31. http://www. ancestry.co.uk/.

63. Testamentary records. England. 1557. RICHINS, Agnes. Will. Collection: Gloucestershire, England, Wills and Inventories, 1541-1858. 1557/11. http://www. ancestry.co.uk/.

64. Testamentary records. England. 1543. COSTERT, William. Will. Collection: Gloucestershire, England, Wills and Inventories, 1541-1858. 1543/70. http://www. ancestry.co.uk/.

65. Testamentary records. England. 1557. SAVERYE, Thomas. Will. Collection: Gloucestershire, England, Wills and Inventories, 1541-1858. 1557/394. http:// www.ancestry.co.uk/.

66. Testamentary records. England. 1551. RICHENS, William. Will. Collection: Gloucestershire, England, Wills and Inventories, 1541-1858. 1551/148. http:// www.ancestry.co.uk/.

67. Testamentary records. England. 1558. JOYNER, Thomas. Will. Collection: Gloucestershire, England, Wills and Inventories, 1541-1858. 1558/460. http:// www.ancestry.co.uk/.

68. Testamentary records. England. 1558. JOYNER, Joan. Will. Collection: Gloucestershire, England, Wills and Inventories, 1541-1858. 1558/134. http:// www.ancestry.co.uk/.

69. Burials (PR) England. Kempsford, Gloucestershire. 30 December 1590. GYNNER, Robert Source reference P189 IN 1/1. Collection: Gloucestershire, England, Church of England Baptisms, Marriages and Burials, 1538-1813. http://www.ancestry.co.uk/.

70. Testamentary records. England. 10 June 1591. GYMER, Robert. Will. Prerogative Court of Canterbury: Will RegistersPROB 11/77/494. The National Archives, Kew, England.

71. Testamentary records. England. 1553. CRIPPES, William. Will. Collection: Gloucestershire, England, Wills and Inventories, 1541-1858. 1553/103. http:// www.ancestry.co.uk/.

72. Burials (PR) England. Kempsford, Gloucestershire. 8 August 1589. GYNNER, William Source reference P189 IN 1/1. Collection: Gloucestershire, England, Church of England Baptisms, Marriages and Burials, 1538-1813. http://www.ancestry.co.uk/.

73. Testamentary records. England. 12 December 1589. GINNER or GYNNER, William Will. Prerogative Court of Canterbury: Will Registers. PROB 11/74/528. The National Archives, Kew, England.

74. Testamentary records. England. 1571. COSTERD, William. Will. Collection: Gloucestershire, England, Wills and Inventories, 1541-1858. 1571/233. http:// www.ancestry.co.uk/.

75. Marriages (PR) England. Kempsford, Gloucestershire. 2 April 1573. GYNNER, William and ROWE, Joane. FHL film no. 956946. Collection: England, Select Marriages, 1538-1973. http://www.ancestry.co.uk/.

76. Testamentary records. England. 1616. GYNNER, Joan. Will. Collection: Gloucestershire, England, Wills and Inventories, 1541-1858. 1616/97. http://www. ancestry.co.uk/.

77. Marriages (PR) England. Hampton Meysey and Marston, Gloucestershire. 18 January 1598. VOASE, James and GYMES, Edith. Source reference P211/1 IN 1/1. Gloucestershire, England, Church of England Baptisms, Marriages and Burials, 1538-1813. http://www.ancestry.co.uk/.

78. Bigland, R. (1792) Historical, monumental and genealogical collections relative to the county of Gloucester; printed from the original papers of the late Ralph Bigland Esa Garter Principal King of Arms. Vol. 2. London: John Nichols.

79. Ross, David. Meysey Hampton, St. Mary's Church. http://www.britainexpress.com/ counties/glouces/churches/Meysey-Hampton.htm.

80. Marshall, Michael L. (2012) The Vaulx family of England, Virginia, and Maryland. Including a discussion of some members of the Vass family of Eastern Virginia. http.//www. bennett-twins.com/documents/GenealogyReports/Vaulx\%20Vass\%20Report.pdf.

81. Blacker, B. H. (1887) Gloucestershire notes and queries. London: William Kent.
82. Testamentary records. England. 1616. HALL, Amy. Will. Collection: Gloucestershire, England, Wills and Inventories, 1541-1858. 1616/3. http://www.ancestry.co.uk/.

83. Testamentary records. England. 9 February 1658. JENNER, Robert. Will. Prerogative Court of Canterbury: Will Registers. PROB 11/273/134. The National Archives, Kew, England.

84. Burials (PR) England. Kempsford, Gloucestershire. 20 November 1638. GENNER, William. Source reference P189 IN 1/1. Collection: Gloucestershire, England, Church of England Baptisms, Marriages and Burials, 1538-1813. http://www.ances try.co.uk/.

85. Testamentary records. England. 23 January 1639. JENNER, William. Will. Prerogative Court of Canterbury: Will Registers. PROB 11/179/108. The National Archives, Kew, England.

86. Testamentary records. England. 26 May 1655. JENNER, Amy. Will. Prerogative Court of Canterbury: Will Registers. PROB 11/245/513. The National Archives, Kew, England.

87. Testamentary records. England. 9 February 1658. JENNER, Robert. Will. Prerogative Court of Canterbury: Will Registers. PROB 11/273/134. The National Archives, Kew, England

88. Marriages (PR) Eisey, Wiltshire. 4 February 1624. JENNER, Alice and HEDGES, Richard. Source reference 633/1. Collection: Wiltshire, England, Marriages, 15381837. http://www.ancestry.co.uk/

89. Marriages (PR) England. Kempsford, Gloucestershire. 6 January 1622. FOARDER William, and GYNNER, Amye. Source reference GDR/V1/138. Collection: Gloucestershire, England, Church of England Baptisms, Marriages and Burials, 1538-1813. http://www.ancestry.co.uk/.

90. Testamentary records. England. 9 February 1658. JENNER, Robert. Will. Prerogative Court of Canterbury: Will Registers. PROB 11/273/134. The National Archives, Kew, England.

91. Testamentary records. England. 1677. SIMMONS, Ann. Will. Collection: Gloucestershire, England, Wills and Inventories, 1541-1858. 1677/9. http://www. ancestry.co.uk/.

92. Testamentary records. England. 1580. COOK, Richard. Will. Collection: Gloucestershire, England, Wills and Inventories, 1541-1858. 1585/134. http:// www.ancestry.co.uk/.

93. Testamentary records. England. 1593. BRISTOW, John. Will. Collection: Gloucestershire, England, Wills and Inventories, 1541-1858. 1594/62. http://www. ancestry.co.uk/.

94. Testamentary records. England. 1597. HEWER, Robert. Will. Collection: Gloucestershire, England, Wills and Inventories, 1541-1858. 1597/167. http:// www.ancestry.co.uk/.

95. Testamentary records. England. 10 June 1591. GYMER, Robert. Will. Prerogative Court of Canterbury: Will Registers. PROB 11/77/494. The National Archives, Kew, England.

96. Herbert, N. M. ed. (1981) 'Kempsford', In: A history of the county of Gloucester. Vol. 7. Oxford: Oxford University Press. pp. 96-105. http://www.british-history.ac.uk/vch/ glos/vol7/pp96-105.

97. Mynors, Rev. A. B. Kempsford. http://www.kempsford.net/history/pdf/history-ofkempsford.pdf.

98. Coaley.net. Men \& armour for Gloucestershire in 1608. http://coaley.net/glos1608/ index.php.

99. Marriages (PR) England. Kempsford, Gloucestershire. 2 June 1578. GYNNER, Joane and ALLIS, Rowland. FHL film no. 956946. Collection: England, Select Marriages, 1538-1973. http://www.ancestry.co.uk/.

100. Testamentary records. England. 1606. AYLIFFE, Rowland. Will. Probate records of the Archdeaconry of Wiltshire. P3/A/5. Wiltshire and Swindon History Centre.

101. Testamentary records. England. 1606. AYLIFFE, Joan. Administration Bond. Probate records of the Archdeaconry of Wiltshire. P3/A/15. Wiltshire and Swindon History Centre.

102. Testamentary Records. England. 15 October 1631. GYNNER, Thomas. Probate records of the Archdeaconry of Wiltshire. P3/G/128. Wiltshire and Swindon History Centre.

103. O(A)T*RIDGE genealogy database. http://homepages.rootsweb.ancestry.com/ otridge/html/fam00272.html.

104. O(A)T*RIDGE genealogy database. http://homepages.rootsweb.ancestry.com/ otridge/html/fam00272.html.

105. The Oatridges of Butler Court. http://homepages.rootsweb.ancestry.com/ otridge/ digest/butlers.htm.

106. Testamentary Records. England. 15 October 1631. GYNNER, Thomas. Probate records of the Archdeaconry of Wiltshire. P3/G/128. Wiltshire and Swindon History Centre. 
107. Testamentary records. England. 17 July 1650. JENNER, John. Will. Prerogative Court of Canterbury: Will Registers. PROB 11/213/190. The National Archives, Kew, England.

108. Testamentary records. England. 21 May 1639, SEABORNE alias PLUMMER or PLUMER, John. Will. Prerogative Court of Canterbury: Will Registers. PROB 11/180/ 213. The National Archives, Kew, England.

109. Testamentary records. Crudwell, Wiltshire, England. 1669. GYNNER, Margaret. Will. Probate records of the Archdeaconry of Wiltshire. P3/G/206. Wiltshire and Swindon History Centre.

110. Testamentary records. England. 17 July 1650. JENNER, John. Will. Prerogative Court of Canterbury: Will Registers. PROB 11/213/190. The National Archives, Kew, England.

111. Burials (PR) England. Malmesbury, Wiltshire. 28 May 1654. GRAYLE, Joane Collection: Wiltshire, England, Church of England Baptisms, Marriages and Burials, 1538-1813. http://www.ancestry.co.uk/.

112. Testamentary records. England. 1640. GRAILE, David. Will/Inventory. Probate records of the Archdeaconry of Wiltshire. P3/G/163. Wiltshire and Swindon History Centre.

113. Sir Henry Modye to John Gymer and Thomas Gymer. Lease of a messuage in Garsdon. 22 October 1616. Leicester and Rutland Record Office. 26D53/1458. http://discovery.nationalarchives.gov.uk/details/r/d572ac3a-e5cb-4868-9266cbde28023d5b

114. Sir Henry Moodye to David Grayle and Robert Grayle, his son. Lease of a messuage in Garsdon. 4 August 1627. Leicester and Rutland Record Office. 26D53/1472 \& 1473. http://discovery.nationalarchives.gov.uk/details/r/88a8413a-cd50-456b-8524182f7767f3bf.

115. Testamentary records. England. 17 December 1651, JENNER, Robert. Will. Prerogative Court of Canterbury: Will Registers. PROB 11/219/736. The National Archives, Kew, England.

116. Testamentary records. England. 1655. GRAYLE, Joan. Collection: UK, Extracted Probate Records, 1269-1975. http://www.ancestry.co.uk/.

117. Lancaster, H. and Coates, B. (2010) 'Jenner, Robert (c.1584-1651), of Widhill, Wilts. and Foster Lane, London'. In: Thrush, Andrew and Ferris, John P., eds. The history of Parliament: the House of Commons 1604-1629. Cambridge: Cambridge University Press. http://www.historyofparliamentonline.org/volume/1604-1629/member/jen ner-robert-1584-1651.

118. Testamentary records. England. 4 March 1659. JENNER or JOMER, Elizabeth. Will. Prerogative Court of Canterbury: Will Registers. PROB 11/289/74. The National Archives, Kew, England.

119. Marriages (PR) England. St Leonard, Foster Lane, London. 15 May 1632. TREVOR, Thomas and JENNER, Anne. Collection: London Marriage Licences 1521-1869. www.findmypast.co.uk.

120. Williams, William Retlaw. (1895) The parliamentary history of the principality of Wales. Brecknock: Davies \& Bell. p. 135. https://archive.org/details/ cu31924030498939.

121. Williams, William Retlaw. (1895) The parliamentary history of the principality of Wales. Brecknock: Davies \& Bell. p. 135. https://archive.org/details/cu31924030498939

122. Sadler, J. (1924) Widhill Chapel and Manor. Wiltshire Archaeological and Natural History Magazine. 42. pp. 11-17.

123. Testamentary records. England. 10 June 1591. GYMER, Robert. Will. Prerogative Court of Canterbury: Will Registers. PROB 11/77/494. The National Archives, Kew, England.

124. O(A)T*ridge genealogy database. http://homepages.rootsweb.ancestry.com/ otridge/html/not01289.html.

125. Lancaster, H. and Coates, B. (2010) 'Jenner, Robert (c.1584-1651), of Widhill, Wilts. and Foster Lane, London'. In: Thrush, Andrew and Ferris, John P., eds. The history of Parliament: the House of Commons 1604-1629. Cambridge: Cambridge University Press. http://www.historyofparliamentonline.org/volume/1604-1629/member/jen ner-robert-1584-1651.

126. Bainbridge, Virginia, ed. (2011) 'Cricklade - Cricklade Borough'. In: A history of the county of Wiltshire. Vol. 18. Woodbridge: Boydell \& Brewer. pp. 20-70. http://www. british-history.ac.uk/vch/wilts/vol18/20-70.

127. Lancaster, H. and Coates, B. (2010) 'Jenner, Robert (c.1584-1651), of Widhill, Wilts and Foster Lane, London'. In: Thrush, Andrew and Ferris, John P., eds. The history of Parliament: the House of Commons 1604-1629. Cambridge: Cambridge University Press. http://www.historyofparliamentonline.org/volume/1604-1629/member/jen ner-robert-1584-1651.

128. Bainbridge, Virginia, ed. (2011) 'Cricklade - Cricklade Borough'. In: A history of the county of Wiltshire. Vol. 18. Woodbridge: Boydell \& Brewer. pp. 20-70. http://www. british-history.ac.uk/vch/wilts/vol18/20-70.

129. Sadler, J. (1924) Widhill Chapel and Manor. Wiltshire Archaeological and Natural History Magazine. 42. pp. 11-17.
130. Lancaster, H. and Coates, B. (2010) 'Jenner, Robert (c.1584-1651), of Widhill, Wilts. and Foster Lane, London'. In: Thrush, Andrew and Ferris, John P., eds. The history of Parliament: the House of Commons 1604-1629. Cambridge: Cambridge University Press. http://www.historyofparliamentonline.org/volume/1604-1629/member/jen ner-robert-1584-1651.

131. Dodsworth, W. (1814) An historical account of the episcopal see and cathedral church, of Salisbury. Salisbury: Brodie \& Dowling. https://archive.org/details/ historicalaccoun00dods.

132. Sadler, J. (1924) Widhill Chapel and Manor. Wiltshire Archaeological and Natura History Magazine. 42. pp. 11-17.

133. Evans, J. T. (1906) The church plate of Gloucestershire, with extracts from the chantry certificates relating to the county of Gloucester by the commissioners of 2 Edward VI (1548) and from the returns of church goods in 6 \& 7 Edward (1562-1563). Bristol: Bristol and Gloucestershire Archaeological Society.

134. Bainbridge, Victoria, ed. (2011) 'Historic parishes - Marston Meysey'. In: A history of the county of Wiltshire. Vol. 18. Woodbridge: Boydell \& Brewer. pp. 210-24. http:// www.british-history.ac.uk/vch/wilts/vol18/210-224

135. Sherlock, P. (2000) Monumental inscriptions of Wiltshire. An edition, in facsimile, of monumental inscriptions in the County of Wilton, by Sir Thomas Phillipps, 1822. Trowbridge: Wiltshire Record Society. http://www.wiltshirerecordsociety.org.uk/ pdfs/wrs_v53.pdf.

136. Testamentary records. England. 12 March 1670. JENNER, William. Will. Prerogative Court of Canterbury: Will Registers. PROB 11/332/400. The National Archives, Kew, England.

137. Testamentary records. England. 26 May 1655. JENNER, Amy. Will. Prerogative Court of Canterbury: Will Registers. PROB 11/245/513. The National Archives, Kew, England.

138. Testamentary records. England. 25 October 1650. JAGUES alias JAGUETTS, Alice Prerogative Court of Canterbury: Will Registers. PROB 11/213/729. The National Archives, Kew, England.

139. Marriages (PR) England. Bibury, Gloucestershire. 2 May 1658. JENNER, Katerin and HALL, William. Source reference P44 IN 1/1. Collection: Gloucestershire Church of England Baptisms, Marriages and Burials, 1538-1813. http://www.ancestry.co.uk/.

140. Marriages (PR) England. Barnsley, Gloucestershire. 26 April 1666. JENNER, Alice and GREENWAY, John. Source reference P34 IN1/2. Collection: Gloucestershire Church of England Baptisms, Marriages and Burials, 1538-1813. http://www. ancestry.co.uk/

141. Baptisms (BT) England, Meyseyhampton, Gloucestershire. 15 April 1638. JENNER, Thomas GDR/V1/155. Collection: Gloucestershire Church of England Baptisms, Marriages and Burials, 1538-1813. http://www.ancestry.co.uk/.

142. Marriages (PR) England. Kempsford, Gloucestershire. 1 August 1671. JENNER Thomas and RANCE, Elizabeth. Source reference GDR/N1/138. Collection: Gloucestershire Church of England Baptisms, Marriages and Burials, 1538-1813. http://www.ancestry.co.uk/

143. Burials (BT) England. Meysey Hampton with Marston Meysey, Gloucestershire. 18 August 1670. JENNER, Marie. Source reference GDR/1/155. Collection: Gloucestershire, England, Church of England Baptisms, Marriages and Burials, 1538-1813. http://www.ancestry.co.uk/.

144. Baptisms (PR) England. Meysey Hampton and Marston Meysey, Gloucestershire. 6 June 1672. JENNER, John. Collection: Gloucestershire, England, Church of England Baptisms, Marriages and Burials, 1538-1813. http://www.ancestry.co.uk/.

145. Fynmore, R. J. (1914) 'Jenner of Gloucestershire and Wiltshire.' In: Holworthy, Richard, ed. Gloucestershire notes and queries. Vol. 10. London: St Catherine Press. pp. 49-59. https://archive.org/details/gloucestershiren810lond.

146. Baptisms (PR) England. Meysey Hampton and Marston Meysey, Gloucestershire. 18 November 1675. JENNER, Robert. Collection: Gloucestershire, England, Church of England Baptisms, Marriages and Burials, 1538-1813. http://www.ancestry.co.uk/.

147. Baptisms (PR) England. Meysey Hampton and Marston Meysey, Gloucestershire. 6 September 1679. JENNER, Elizabeth. Collection: Gloucestershire, England, Church of England Baptisms, Marriages and Burials, 1538-1813. http://www.ancestry.co.uk/.

148. Marriages (PR) England. Inglesham, Gloucestershire. 27 December 1676. JENNER, John, and JACOB, Mary. Collection: Wiltshire, England, Marriages, 1538-1837. http://www.ancestry.co.uk/

149. Testamentary records. England. 12 March 1670. JENNER, William. Will. Prerogative Court of Canterbury: Will Registers. PROB 11/332/400. The National Archives, Kew, England.

150. Testamentary records. England. 2 March 1700. JENNER, John. Will. Prerogative Court of Canterbury: Will Registers. PROB 11/454/357. The National Archives, Kew, England.

151. Evans, J. T. (1906) The church plate of Gloucestershire, with extracts from the chantry certificates relating to the county of Gloucester by the commissioners of 2 Edward V 
(1548) and from the returns of church goods in 6 \& 7 Edward (1562-1563). Bristol: Bristol and Gloucestershire Archaeological Society.

152. Bainbridge, Virginia, ed. (2011) 'Historic Parishes - Lydiard Millicent'. In: A history of the county of Wiltshire. Vol. 18. Woodbridge: Boydell \& Brewer. pp. 186-209. http:// www.british-history.ac.uk/vch/wilts/vol18/186-209.

153. Foster, Joseph, ed. (1891) 'Jablonski-Juxston'. In: Alumni Oxonienses 1500-1714. Oxford: University of Oxford. pp. 793-836. http://www.british-history.ac.uk/ alumni-oxon/1500-1714/pp793-836.

154. Wiltshire notes and queries. Vol. 1. Devizes: George Simpson. p. 283. https://archive org/details/wiltshirenotesqu01deviuoft.

155. Testamentary records. England. 1690. JENNER, William. Will. Collection: Gloucestershire, England, Wills and Inventories, 1541-1858. 1699/178. http:// www.ancestry.co.uk/.

156. Testamentary records. England. 7 February 1690. JENNER, John. Will. Prerogative Court of Canterbury: Will Registers. PROB 11/398/227. The National Archives, Kew, England.

157. Burials (PR) England. Westcote, Gloucestershire. 22 April 1698. COLLETT, John. Source reference P356 IN 1/1. Collection: Gloucestershire, England, Church of England Baptisms, Marriages and Burials, 1538-1813. http://www.ancestry.co.uk/.

58. Baptisms (PR) England. Westcote, Gloucestershire. 20 March 1670. COLLETT, Walter P356 IN 1/1. Collection: Gloucestershire, England, Church of England Baptisms, Marriages and Burials, 1538-1813. http://www.ancestry.co.uk/.

159. Frith, Brian, ed. (1954) Gloucestershire Marriage Allegations. Vol. 1. Bristol: Bristol and Gloucestershire Archaeological Society.

160. Burials (PR) England. Westcote, Gloucestershire. 22 April 1698. FURLEY, Clement. Source reference P356 IN 1/1. Collection: Gloucestershire, England, Church of England Baptisms, Marriages and Burials, 1538-1813. http://www.ancestry.co.uk/.

161. Testamentary records. England. 9 February 1658. JENNER, Robert. Will. Prerogative Court of Canterbury: Will Registers. PROB 11/273/134. The National Archives, Kew, England.

162. Baptisms (PR) England, Kempsford, Gloucestershire. 21 May 1655. JENNER, Katheren. Collection: England, Select Births and Christenings, 1538-1975. http:// www.ancestry.co.uk.

163. Frith, Brian, ed. (1954) Gloucestershire Marriage Allegations. Vol. 1. Bristol: Bristol and Gloucestershire Archaeological Society.

164. Burials (PR) England. Kempsford, Gloucestershire. 3 February 1688. JENNER, Robert. Source reference P189 IN 1/3. Gloucestershire, England, Church of England Baptisms, Marriages and Burials, 1538-1813. http://www.ancestry.co.uk/.

165. Testamentary records. England. 1710. JENNER, Jane. Will. Collection: Gloucestershire, England, Wills and Inventories, 1541-1858. 1710/150. http:// www.ancestry.co.uk/.

166. Testamentary records. England. 17 December 1651, JENNER, Robert. Will. Prerogative Court of Canterbury: Will Registers. PROB 11/219/736. The National Archives, Kew, England.

167. Sadler, J. (1924) Widhill Chapel and Manor. Wiltshire Archaeological and Natural History Magazine. 42. pp. 11-17.

168. Bainbridge, Virginia, ed. (2011) 'Cricklade - Outer Cricklade'. In: A history of the county of Wiltshire. Vol. 18. Woodbridge: Boydell \& Brewer. pp. 70-108. http://www. british-history.ac.uk/vch/wilts/vol18/70-108

169. Bagwell, R. (2013) 'Marsh, Narcissus'. In: Dictionary of national biography, 1885-1900. Vol. 36. London: Smith, Elder. https://en.wikisource.org/wiki/Marsh,_Narcissus_(DNB00).

170. Friends of Lydiard Tregoz. Report No. 40. p. 28. https://www.friendsoflydiardpark org.uk/projects.html.

171. Testamentary records. England. 25 November 1732, JENNER, Nathaniel. Will. Prerogative Court of Canterbury: Will Registers. PROB 11/655/95. The National Archives, Kew, England.

172. Apprenticeship Record. London, England. JENNER, Nathaniel, son of JENNER, John of Widhill, Wiltshire. Apprenticed for seven years to WHITMEY, William. 10 August 1685. Collection: London, England, Freedom of the City Admission Papers, 1681 1930. www.http://ancestry.co.uk

173. Bainbridge, Virginia, ed. (2011) 'Cricklade - Outer Cricklade'. In: A history of the county of Wiltshire. Vol. 18. Woodbridge: Boydell \& Brewer. pp. 70-108. http://www. british-history.ac.uk/vch/wilts/vol18/70-108.

174. Marriages (PR) England. Erlestoke, Wiltshire. 16 March 1707. JENNER, Nathaniel, and ADEE, Katherine. Collection: Wiltshire England, Marriages, 1538-1837. http://www. ancestry.co.uk/.

175. Sherlock, P. (2000) Monumental inscriptions of Wiltshire. An edition, in facsimile, of monumental inscriptions in the County of Wilton, by Sir Thomas Phillipps, 1822. Trowbridge: Wiltshire Record Society. http://www.wiltshirerecordsociety.org.uk/ pdfs/wrs v53.pdf.

176. Honorable Society of Lincoln's Inn (1896) The records of the Honorable Society of Lincoln's Inn. Vol. 1. p. 366. https://archive.org/details/NOL114201799.
177. Sherlock, P. (2000) Monumental inscriptions of Wiltshire. An edition, in facsimile, of monumental inscriptions in the County of Wilton, by Sir Thomas Phillipps, 1822. Trowbridge: Wiltshire Record Society. http://www.wiltshirerecordsociety.org.uk/ pdfs/wrs_v53.pdf.

178. Marriages (PR) England. Eisey, Wiltshire. 23 February 1748. JENNER, Nathaniel and PARKER, Catherine. Collection: Wiltshire England, Marriages 1538-1837. http:// www.ancestry.co.uk/.

179. Baptisms (PR) England. Broad Blunsdon, Wiltshire. 5 April 1761. JENNER, Mary. Collection: Wiltshire, England, Church of England Baptisms, Marriages and Burials, 1538-1813. http://www.ancestry.co.uk/.

180. Sadler, J. (1924) Widhill Chapel and Manor. Wiltshire Archaeological and Natural History Magazine. 42. pp. 11-17.

181. Testamentary records. England. 14 April 1764, JENNER, Nathaniel. Will. Prerogative Court of Canterbury: Will Registers. PROB 11/897/380. The National Archives, Kew, England.

182. Sadler, J. (1924) Widhill Chapel and Manor. Wiltshire Archaeological and Natural History Magazine. 42. pp. 11-17.

183. Testamentary records. England. 17 December 1651, JENNER, Robert. Will. Prerogative Court of Canterbury: Will Registers. PROB 11/219/736. The National Archives, Kew, England.

184. Bainbridge, Virginia, ed. (2011) 'Historic parishes - Marston Meysey'. In: A history of the county of Wiltshire. Vol. 18. Woodbridge: Boydell \& Brewer. pp. 210-24. http:// www.british-history.ac.uk/vch/wilts/vol18/210-224

185. Bainbridge, Virginia, ed. (2011) 'Historic parishes - Marston Meysey'. In: A history of the county of Wiltshire. Vol. 18. Woodbridge: Boydell \& Brewer. pp. 210-24. http:// www.british-history.ac.uk/vch/wilts/vol18/210-224.

186. Testamentary records. England. 2 March 1700. JENNER, John. Will. Prerogative Court of Canterbury: Will Registers. PROB 11/454/357. The National Archives, Kew, England.

187. Bainbridge, Virginia, ed. (2011) 'Historic parishes - Marston Meysey'. In: A history of the county of Wiltshire. Vol. 18. Woodbridge: Boydell \& Brewer. pp. 210-24. http:// www.british-history.ac.uk/vch/wilts/vol18/210-224.

188. Baptisms (PR) England. Meysey Hampton, Gloucestershire. October 1684. JENNER Jacob. Bishop's Transcripts. GDR/v1/155. Collection: Gloucestershire, England, Church of England, Baptisms, Marriages and Burials, 1538-1813. http://www.ancestry.co.uk/.

189. Baptisms (PR) England. Hampton and Marston Meysey, Gloucestershire. 4 November 1686. JENNER, Suzanne. Collection: Gloucestershire, England, Church of England, Baptisms, Marriages and Burials, 1538-1813. http://www.ancestry.co.uk/.

190. Testamentary records. England. 11 February 1717. JENNER, John. Prerogative Court of Canterbury: Will Registers. PROB 11/556/264. The National Archives, Kew, England.

191. Testamentary records. England. 1743. JENNER, Robert. Will. Collection: Gloucestershire, England, Wills and Inventories 1541-1858. 1743/96. http://www. ancestry.co.uk/.

192. Testamentary records. England. 11 January 1788, JENNER, John. Will. Prerogative Court of Canterbury: Will Registers. PROB 11/1161/108. The National Archives, Kew, England.

193. Herbert, N. M., ed. (1981) 'Southrop'. In: A history of the county of Gloucester. Vol. 7. Oxford: Oxford University Press. pp. 129-36. http://www.british-history.ac.uk/vch/ glos/vol7/pp121-136.

194. Testamentary records. England. 10 March 1831, JENNER, Mary. Will. Prerogative Court of Canterbury: Will Registers. PROB 11/1783/41. The National Archives, Kew, England.

195. Bainbridge, Virginia, ed. (2011) 'Historic parishes - Marston Meysey'. In: A history of the county of Wiltshire. Vol. 18. Woodbridge: Boydell \& Brewer. pp. 210-24. http:// www.british-history.ac.uk/vch/wilts/vol18/210-224.

196. Urban, Sylvanus. (1814) The Jenner family. The Gentleman's Magazine: and Historical Chronicle. 84(2). p. 116. https://books.google.co.uk.

197. Henning, B. D. (1983) 'Jenner, Sir Thomas (c.1638-1707), of Petersham, Surr.'. In: Henning, B. D., ed. The history of Parliament: the House of Commons 1660-1690. Cambridge: Cambridge University Press. http://www.historyofparliamentonline org/volume/1660-1690/member/jenner-sir-thomas-1638-1707.

198. Burke, B. (1894) A genealogical and heraldic history of the landed gentry of Great Britain \& Ireland. London: Harrison. https://archive.org/stream/genealogicalhera01 byuburk\# page/866/mode/2up.

199. Henning, B. D. (1983) 'Jenner, Sir Thomas (c.1638-1707), of Petersham, Surr.'. In: Henning, B. D., ed. The history of Parliament: the House of Commons 1660-1690. Cambridge: Cambridge University Press. http://www.historyofparliamentonline org/volume/1660-1690/member/jenner-sir-thomas-1638-1707.

200. Henning, B. D. (1983) 'Jenner, Sir Thomas (c.1638-1707), of Petersham, Surr.'. In: Henning, B. D., ed. The history of Parliament: the House of Commons 1660-1690. 
Cambridge: Cambridge University Press. http://www.historyofparliamentonline. org/volume/1660-1690/member/jenner-sir-thomas-1638-1707.

201. Jenner, Henry. (1892) 'Jenner, Thomas (1637-1707)'. In: Dictionary of national biography. Vol. 29. London: Smith, Elder \& Co. https://en.wikisource.org/wiki/ Jenner,_Thomas_(1637-1707)_(DNB00).

202. Henning, B. D. (1983) 'Jenner, Sir Thomas (c.1638-1707), of Petersham, Surr.'. In: Henning, B. D., ed. The history of Parliament: the House of Commons 1660-1690. Cambridge: Cambridge University Press. http://www.historyofparliamentonline. org/volume/1660-1690/member/jenner-sir-thomas-1638-1707.

203. Henning, B. D. (1983) 'Jenner, Sir Thomas (c.1638-1707), of Petersham, Surr.'. In: Henning, B. D., ed. The history of Parliament: the House of Commons 1660-1690. Cambridge: Cambridge University Press. http://www.historyofparliamentonline. org/volume/1660-1690/member/jenner-sir-thomas-1638-1707.

204. Berry, William (1828) 'Jenner, [London]'. In: Encyclopaedia heraldica or complete dictionary of heraldry. Vol. 2. London: Sherwood, Gilbert \& Piper. https://books. google.co.uk.
205. Burke, B. (1894) A genealogical and heraldic history of the landed gentry of Great Britain \& Ireland. London: Harrison. https://archive.org/stream/genealogicalhera01 byuburk\# page/866/mode/2up.

206. Baptisms (PR) England. Shrivenham, Berkshire. 4 March 1575. JOYNER, Agnes. Collection: England, Select Births and Christenings, 1538-1975. http://www.ances try.co.uk/.

207. The chaplains of Fromond's Chantry at Winchester. (1916) Notes and Queries. Series 12. Vol. 2. p. 223. https://archive.org/stream/s12notesqueries02londuoft\#page/222/ mode/2up.

208. The chaplains of Fromond's Chantry at Winchester. (1916) Notes and Queries. Series 12. Vol. 2. p. 223. https://archive.org/stream/s12notesqueries02londuoft\#page/222/ mode/2up.

209. The chaplains of Fromond's Chantry at Winchester. (1916) Notes and Queries. Series 12. Vol. 2. p. 223. https://archive.org/stream/s12notesqueries02londuoft\#page/222/ mode/2up.

\section{ABOUT THE AUTHOR}

PD Dr. John Chandler, MA (Social Sciences), MA (Translation Studies), AVCM, CBiol, FRSB, is a university researcher and lecturer in plant molecular developmental genetics at the University of Cologne in Germany. In addition to his many musical interests, he has a long-standing interest in genealogy and local history.

\section{Email: flori43@hotmail.com.}

https://orcid.org/0000-0002-3188-5628 